\title{
Erratum to: 'A cost and performance comparison of Public Private Partnership and public hospitals in Spain'
}

Maria Caballer-Tarazona ${ }^{1 *}$ and David Vivas-Consuelo ${ }^{2}$

Unfortunately, the original version of this article [1] contained an error. The author list was included incorrectly. Antonio Clemente-Collado was included as one of the authors by mistake. This author has now been removed from the author list as there was a conflict of interest. There will also be an update to correct this.

\footnotetext{
Author details

${ }^{1}$ Applied Economics Department, Universitat de València, Valencia, Spain.

${ }^{2}$ Research Centre for Health Economics and Management, Universitat

Politècnica de València, Valencia, Spain.
}

Received: 23 May 2016 Accepted: 23 May 2016

Published online: 02 June 2016

\section{Reference}

1. Caballer-Tarazona M, Vivas-Consuelo D. A cost and performance comparison of Public Private Partnership and public hospitals in Spain. Heal Econ Rev. 2016;6:17.

Submit your manuscript to a SpringerOpen ${ }^{\circ}$ journal and benefit from:

- Convenient online submission

Rigorous peer review

- Immediate publication on acceptance

- Open access: articles freely available online

- High visibility within the field

- Retaining the copyright to your article

Submit your next manuscript at $>$ springeropen.com 